\title{
Baseball as an Intersection of Popular Culture and North American Exploitation in the Dominican Republic
}

\section{Tiffany Gurprasad}

$* * *$

Baseball in the Dominican Republic has come to signify not only an expressive form of Dominican patriotism, but an outlet for economic relief. Although the sport is intertwined with a history of American occupation and dominance, baseball in the Dominican Republic contrasts that of the American game. As with many other Caribbean countries such as Cuba and Puerto Rico, Dominican baseball was developed in the sugar refineries and sustained by Cuban, West Indian and Haitian labourers ${ }^{1}$. Dominican talent has and continues to be channeled out of the country and into North American teams through recruitment academies, providing young athletes the narrow possibility of an escape from poverty. "Outside of the United States, the Dominican Republic produces more professional and major league players than any other country." It is this disproportion between all-star success and Dominican unemployment that creates an intensity which fosters young men to depend on baseball. The constant recruitment and extraction of Dominican players into North American leagues can be compared to the historical and contemporary consumption of the Caribbean as a whole, a site of temporality where goods and bodies exist only for consumption. ${ }^{3}$ American dominance not only penetrates and stifles baseball within the Dominican, but also exploits Dominican athletes that enter the MLB (Major League Baseball). Baseball is a

Alan Klein, Sugarball: The American Game, The Dominican Dream (New Haven: Yale University Press, 1991), p16.

${ }^{2}$ Alan Klein, 2.

${ }^{3}$ Mimi Sheller, Consuming the Caribbean (London: Routledge, 2003), p26. 


\section{CARIBBEAN QUILT | 2011}

vital expression of Dominican nationalism, inseparable from the country's history and politics, but it is also inextricably intertwined with North American exploitation. This tension between culture and politics is a fundamental element of Dominican baseball.

Baseball was introduced to Cuba in the late nineteenth century, after the country shifted its economic dependence from Spain to the United States. ${ }^{4}$ A combination of Cubans and Americans were responsible for the development and integration of baseball in the Dominican Republic. Cuban exiles from the Ten-Year War brought baseball to Hispaniola, and the sport was further popularized by Americans who invented the game and were increasingly present as symbols of power in the nation. ${ }^{5}$ The influence of US hegemony both politically and culturally is seen in the way soccer, a Spanish import to the Dominican Republic, was overshadowed by baseball. ${ }^{6}$ Although the first official teams and players were from wealthy families, "baseball culture" in the Dominican was fuelled by its presence in the sugar cane fields. "The Dominican was the preferred destination of men and women from the British West Indies and from Puerto Rico prior to the turn of the century, and after 1910, of Haitians and less so of residents of the former English colonies."7 These immigrants replaced Dominican labourers on sugar refineries when Dominican peasants refused to work for the wages offered. ${ }^{8}$ The game of baseball was played in such refineries, diverting labourers during slow harvests and fostering a strong sense of community and identity; it also created its own cultural legacy. As the popularity of baseball increased, refinery managers offered cash payments to cane-cutters to field good teams, which began competing on a high level. ${ }^{9}$ Intense rivalry and competition also surged throughout the cities, with the two most popular professional teams, Leones del Escogido and Tigres del Licey.

${ }^{4}$ Rob, Ruck, The Tropic of Baseball: Baseball in the Dominican Republic (London: Meckler, 1991), 2.

${ }^{5}$ Klein, 16.

${ }^{6}$ Ruck, 6.

${ }^{7}$ Teresita Martinez-Vergne, Nation \& Citizen in the Dominican Republic, 18801916 (Chapel Hill: University of North Carolina Press, 2009), 86.

${ }^{8}$ Martinez-Vergne, 86.

${ }^{9}$ Klein, 151. 
Tiffany Gurprasad - BASEBALL AS AN INTERSECTION OF POPULAR CULTURE AND NORTH AMERICAN EXPLOITATION IN THE DOMINICAN REPUBLIC

Licey blue and Escogido red acted as the two most authentic representations of baseball and rivalry in the sport, encompassing the essence of Dominican baseball. "More than twenty thousand paid to attend the championship games in 1921 at a time when Santo Domingo's population was only a bit over thirty thousand." ${ }^{10}$ Licey and Escogido are so deeply rooted in Dominican nationality they have come to represent the two dominant cultures of masculinity in the nation. According to Antonio De Moya, there is a dominant "rebellious" street culture of "tigueres" that is contrasted to the dominant "courageous" household culture of the "leones." 11 Baseball has historically brought together the population as a game that transgressed race and class, linking together athletes, families, fans and villages.

While professional baseball in the Dominican experienced a rollercoaster of success and decline from 1921 through 1950, amateur baseball never ceased to fade, signifying that Dominican passion in baseball is not "mediated by money or international acclaim." 12 Politics were firmly entrenched in Dominican baseball in 1936, with Trujillo "combining Licey and Escogido and sponsoring the best ballplayers of the North American black leagues to create an invincible machine of a team." ${ }^{13}$ The merger of the two teams into the single Ciudad Trujillo, the costs of bringing top players from foreign countries, along with Trujillo's underlying political stake in the game caused interest in professional baseball to wane. After baseball's decline in 1950, the era of "beisbolromantico" made its mark on the Dominican Republic. The term "beisbolromantico" was established to describe the specific quality of Dominican baseball, from the immediacy of the game to the fervent, emotional connection of fans and players. The 'romantico' quality was able to develop because Dominican baseball was at first overlooked by Americans. Players and teams from the sugar refineries, specifically San Pedro de Macoris, largely fed the popular professional teams.

\footnotetext{
${ }^{10}$ Ruck, 12 .
}

11 Antonio De Moya, "Power Games and Totalitarian Masculinity in the Dominican Republic," in Interrogating Caribbean Masculinities ed. Rhoda Reddock (Kingston: University of West Indies Press, 2004), p80.

${ }^{12}$ Klein, 23. 


\section{CARIBBEAN QUILT | 2011}

Amateur baseball plays a significant role in Dominican history; San Pedro de Macoris has gained local and international recognition for its teams and players. "Beisbolromantico" is genuinely expressed through amateur play in the sugar refineries where "life remained a struggle, and the harder it was the brighter looked the path lit by baseball."14 However, after 1955, when North America began taking a special interest in Dominican players, Dominican baseball became increasingly dependent upon the MLB and therefore the (North) American game.

From the mid-fifties onwards, Major League Baseball became a magnet for Dominican players, which not only affected the prosperity of Dominican athletes and their families, but Dominican baseball as a whole. The extraction of the top players from the amateur leagues to professional leagues, and then from professional leagues to the MLB, immensely affected the competitiveness of the Dominican game. "1947 onwards marked racial integration in American baseball with players such as Jackie Robinson and Larry Doby opening up the field of organized baseball for Latin American players." 15 The development of professional leagues in the Dominican Republic created an intense relationship between Dominican and American baseball. According to Alan Klein, "the number of Dominicans playing professional baseball in North America began as a trickle in the late 1950s, and then grew to 49 between 1955 and 1980 and to hundreds in the 1980s." ${ }^{16}$ With the Dominican winter league changing seasons to correlate perfectly with North America's summer league, the MLB found opportunities to harness the raw talent they witnessed in the Dominican game. "Overall, a third of the two-hundred ball players in the Toronto organization come from the Dominican Republic or elsewhere in the Caribbean." 17 Latin America and the Caribbean's contribution to North American baseball was seemingly inexhaustible, and 'by the end of the 1960's, no fan of the game could have doubted the impact that the Caribbean basin

\footnotetext{
${ }^{14}$ Klein, 32.

${ }^{15}$ Adrian Burgos Jr, Playing America's Game: Baseball, Latinos, and the Color Line (Berkeley: University of California Press, 2007), p180.

${ }^{16}$ Klein, 35 .

${ }^{17}$ Ruck, 62. 
Tiffany Gurprasad - BASEBALL AS AN INTERSECTION OF POPULAR CULTURE AND NORTH AMERICAN EXPLOITATION IN THE DOMINICAN REPUBLIC was making on major league ball." ${ }^{18}$ In turn, Dominican athletes saw Major League Baseball as the "personification of the American dream of opportunity, upward social mobility, and success." 19

Unfortunately, the motivations behind scouting Latin American ball players were the cheap wages they would be paid in comparison to their American counterparts. "With increasing disparity, in 1975 Majorleague organizations gave US-born players selected in the amateur draft an average signing bonus of $\$ 65,000$ while signing bonuses for foreignborn Latin Americans averaged \$5,000." ${ }^{20}$ Many Latin American ball players enter North American baseball in positions of vulnerability, and with few economic opportunities available back home, many have no option but to settle for low wages. Major-leagues in North America are more than willing to take advantage of this situation, offering foreignborn players inferior wages in comparison to Americans. The Dominican-American baseball superstar Alex Rodriguez was selected from an amateur draft and signed with a bonus of $\$ 1.3$ million US. He recognizes the benefits of US citizenship and the sharp financial disparity, quoted as saying "I'm really grateful I was born and raised in the United States...I'm sure I would have been a top prospect in the Dominican, but maybe I would have gotten $\$ 5,000$, I would have been on a much tougher road." 21

Baseball academies were set up in the Dominican Republic as institutions that produce and maintain players for North American major leagues, "the first academy was built just north of Santo Domingo by the Toronto Blue Jays in 1977."22 The baseball academy acts to lure in boys and young men with the prospect of the "American Dream" and a chance at signing with an MLB team. Before the Dominican government intervened in the practices of these academies in 1984, boys as young as thirteen were being recruited, separated from

\footnotetext{
${ }^{18}$ Ruck, 101.

19 Samuel Regalado, Viva Baseball! Latin Major Leaguers and Their Special Hunger (Urbana: University of Illinois Press, 1998), p2.

${ }^{20}$ Burgos Jr, 232.

${ }^{21}$ Burgos Jr, 233.

${ }^{22}$ Klein, 42.
} 


\section{CARIBBEAN QUILT | 2011}

their families, underpaid, and denied education. ${ }^{23}$ The academies commoditize young athletes and take advantage of Dominican talent while undermining baseball in the nation they are based in. Mimi Sheller writes, "The Caribbean has been repeatedly imagined and narrated as a tropical paradise in which the land, plants, resources, bodies, and cultures of its inhabitants are open to be invaded, occupied, bought, moved, used, viewed, and consumed in various ways." ${ }^{24}$ From this perspective, the MLB indulges in the Caribbean's colonial past, extracting talent from the Dominican without regard for the country itself. For North American major leagues, the Dominican is a site imagined outside of their modernity where players can be funneled solely for the success of their various teams. Klein compares baseball academies in the Dominican to colonial outposts: "it finds the raw materials (talented athletes), refines them (trains the athletes), and ships abroad the finished product (baseball players)." 25

Hence, perceptions of the American dream often came with harsh realities for the majority of players that migrated north to play baseball. The pressure from back home to succeed, the hardships of displacement and settlement along with sudden American acculturation were all consequences of baseball migration. Issues of orientation to a new culture and the perceived grandeur of American capitalism were often overwhelming for Latin American players. ${ }^{26}$ The processes of migration for Dominican players to the MLB still to this day place them in vulnerable positions, where language barriers, racial discrimination, isolation from a traditional community-orientated space and pressure to perform all amalgamate to work against the athlete. "Latin players rarely landed in a town that held vestiges of Spanish-speaking culture, and this disadvantage set them apart from other new-comers to the United States." ${ }^{27}$ This is summed up in the 2008 film, Sugar, where

\footnotetext{
${ }^{23}$ Klein 43.

${ }^{24}$ Sheller, 13.

${ }^{25}$ Klein, 42.

${ }^{26}$ Relagado, 61.

${ }^{27}$ Samuel Relagado, "Sammy Sosa Meets Horatio Alger: Latin Ballplayers and the American Success Myth," in Baseball and the American Dream, ed Robert Elias (London: M.E. Sharpe, 2001), p74.
} 
Tiffany Gurprasad - BASEBALL AS AN INTERSECTION OF POPULAR CULTURE AND NORTH AMERICAN EXPLOITATION IN THE DOMINICAN REPUBLIC

Miguel Santos is recruited after his second year of high-school to the minor leagues in America. Sugar intensely captures the narrow, burdensome path baseball creates into the Western world for Dominican players, the struggle of adjusting to American culture and the everlooming machine of the MLB that commodifies Latin American and Caribbean players. ${ }^{28}$ Since leagues in the Dominican and other Latin American countries were racially inclusive, entering a culture where 'integration' was a new idea would also firmly shape the experience of Latin American players.

Accustomed to racially inclusive leagues in the Caribbean and Latin America, players who migrated to American baseball were largely unprepared for the level of discrimination and racism entrenched in American society. Latin American players of Roberto Clemente's era (mid 1950's) “often perceived American racism as a minor inconvenience in their quest for glory, and were constantly warned by older, experienced players of the pitfalls ahead. ${ }^{29}$ Players were racially contrasted to their American counterparts, having any mistake or shortcoming blamed on ethnicity. Latin American ball players, whether Afro-Caribbean or Hispanic-Caribbean, were stereotyped as being hottempered and lacking mental alertness. ${ }^{30}$ The polarization between Americans and Latin Americans still exists and constantly reminds Latin American players of their presence in "America's game." Clemente was quoted as saying, "there's a collective mentality in the United States that Hispanics aren't worth much;" 31 this is taken up further in the film Sugar, where fans angrily call Dominican-born Miguel "Sugar" Santos a "fucking Puerto-Rican.", The racism born out of refusing to recognize cultural difference further isolates players who enter the MLB, alienating them from a sense of belonging in the society. "The racial components compounded Latin American ballplayer's struggle to adapt to other facets of American culture and the inability to communicate in English magnified their already isolated

\footnotetext{
${ }^{28}$ Sugar. DVD. Directed by Anna Boden. 2008; USA.Journeyman Pictures, 2008.

${ }^{29}$ Relagado, 70.

${ }^{30}$ Ruck, 83.

${ }^{31}$ Relagado, 204.

${ }^{32}$ Sugar, 2008.
} 


\section{CARIBBEAN QUILT | 2011}

circumstances." 33 This alienation is also laced within the constant pressure of being replaced by other desperate, foreign-born players or falling short of American expectations ${ }^{34}$. Migration through baseball for Dominican and Latin American born players is loaded with social inequalities that actively position ball players to be exploited by the MLB.

The association between baseball and the American dream needs to be re-thought when considering the role of Dominican (or any Caribbean/Latin American) players. While the notion of the American dream sets up America as "the land of opportunity where sufficient dedication and hard work guarantees individual mobility and success" 35 , the dream needs to be seen in light of the persisting entanglement of racial, social and economic inequalities. Young men in the Dominican Republic are heavily influenced by the appeal of massive financial gain that American baseball offers, which is starkly contrasted to the reality of impoverishment and unemployment in the nation. "Many Dominican boys see baseball as their only escape, and the inordinate pull of the sport over them is strengthened by the astounding success that the best Dominican players have achieved in North American professional baseball." 36 The systematic dependence on American baseball for autonomy fosters the importance of baseball in the Dominican Republic, not only as a marker of national pride, but as an economic outlet for young men and their families. Once athletes migrate, the immense pressure of baseball as an alley out of poverty along with cultural alienation often leads to young Dominican athletes abandoning their "American dream" of baseball stardom. The lack of education that is systematically perpetuated through early recruitment in baseball academies gives ballplayers little economic opportunity if they wish to pursue a different path. For the baseball organizations, "signing players at an early age is cost-efficient since players are more expensive

\footnotetext{
${ }^{33}$ Relagado, 75 .

${ }^{34}$ Sugar, 2008.

${ }^{35}$ Robert Elias, "A Fit for a Fractured Society," in Baseball and the American Dream, ed. Robert Elias(London: M.E. Sharpe, 2001), p6.

${ }^{36}$ Klein, 58. 
Tiffany Gurprasad - BASEBALL AS AN INTERSECTION OF POPULAR CULTURE AND NORTH AMERICAN EXPLOITATION IN THE DOMINICAN REPUBLIC when they are more seasoned." 37 "Most of the baseball players from the United States graduate high-school, whereas in the Dominican Republic they rarely get through the sixth grade." ${ }^{38}$ This contrast of Dominican and American players shows the severe vulnerability Dominicans are subjected to within the major-leagues. Unlike the majority of their American counterparts, baseball is often the only option for Dominican players.

Baseball is an integral part of the Dominican Republic's culture, used both as a national pastime and as a tool of resistance against American hegemony. For many Dominicans, the game is seen as an expression of their superior athletic capacities in the sport. ${ }^{39}$ During the American occupation, Dominicans fraternized and resisted through representing the Dominican flag in baseball games. Baseball is not viewed as a facet of American imperialism in the Dominican Republic; it is instead valued for its Dominican diversity and quality. The history of baseball tied with sugar refineries and the West-Indian "Cocolo's"" contributions to the sport are all nostalgic elements that serve as the foundation of the Dominican game. However, Dominican baseball challenging American dominance is complicated by the nation's dependence on North American major leagues. Institutions like the MLB and their associated baseball academies take advantage of the lure of the American dream and exploit hopeful boys and young men. Migration to North America to play in the MLB is riddled with instability for Dominican players, negatively shaping their lived experience and settlement as members of the diaspora. The role of the Dominican Republic in American baseball cannot be denied, whether through the large amount of players who contribute to the major league teams or the help that Dominican's winter league provides to its minor league players. ${ }^{40}$ Although both countries hold onto baseball as a defining quality of nationality, fans in the United States divide their loyalty between baseball, football and variety of other games while in

\footnotetext{
${ }^{37}$ Klein, 93.

${ }^{38}$ Klein, 80.

${ }^{39}$ Ruck, 26.

${ }^{40}$ Ruck, 111.
} 


\section{CARIBBEAN QUILT | 2011}

D.R, baseball is a year round sport. ${ }^{41}$ Baseball exceeds the title of national pastime because it signifies much more, such as the success of young prospective athletes, families dependent on their son's baseball careers, memories of intense political turmoil with Licey and Escogido, beisbolromantico, and the American dream. The saturation of politics into baseball during the Trujillo reign and American occupation allowed the sport to take on a specifically Dominican reality and retain meaning, surpassing sheer recreation and leisure. A complex web of transnational relationships is formed between Caribbean players and North American leagues. To what extent do Dominican players represent Dominican baseball and how do these representations fit into the American game? North America and the Dominican Republic share an intrinsic relationship through baseball that maintains a constant, yet unequal, exchange of memory, culture and people.

\section{Bibliography}

Burgos Jr., Adrian. Playing America's Game: Baseball, Latinos, and the Color Line. Berkeley: University of California Press, 2007.

De Moya, Antonio. "Power Games and Totalitarian Masculinity in the Dominican Republic.'In Interrogating Caribbean Masculinities, edited by Rhoda Reddock, Kingston: University of West Indies Press, 2004.

Elias, Robert. "A Fit for a Fractured Society.'In Baseball and the American Dream, edited by Robert Elias, London: M.E. Sharpe, 2001. Joyce, Gare. The Only Ticket Off The Island. Toronto: Lester \&OrphenDennys, 2002.

\footnotetext{
${ }^{41}$ Gare Joyce, The Only Ticket Off The Island (Toronto: Lester \&Orphen Dennys, 1990)p,2.
} 
Tiffany Gurprasad - BASEBALL AS AN INTERSECTION OF POPULAR CULTURE AND NORTH AMERICAN EXPLOITATION IN THE DOMINICAN REPUBLIC

Klein, Alan. Sugarball: The American Game, The Dominican Dream.

New Haven: Yale University Press, 1991.

Martinez-Vergne, Teresita.Nation \& Citizen in the Dominican Republic, 1880-1916. Chapel Hill: University of North Carolina Press, 2009.

Relagado, Samuel. "Sammy Sosa Meets Horatio Alger: Latin Ballplayers and the American Success Myth." In Baseball and the American Dream, edited by Robert Elias, London: M.E. Sharpe, 2001.

Regalado, Samuel. Viva Baseball! Latin Major Leaguers and Their Special Hunger. Urbana: University of Illinois Press, 1998.

Ruck, Rob. The Tropic of Baseball: Baseball in the Dominican Republic. London: Meckler, 1991.

Sheller, Mimi. Consuming the Caribbean. London: Routledge, 2003.

Sugar. DVD. Directed by Anna Boden. 2008; USA.Journeyman Pictures, 2008. 